CheA and the adaptor protein $\mathrm{CheW}$ and localize to the cell pole. This chemosensory complex is thought to be important for effective sensing of and responses to a wide range of stimulation. However, the mechanisms underlying receptor localization and clustering with CheA and CheW are not clear.To study the behavior of chemoreceptors in cell membrane, the aspartate chemoreceptor Tar fused to GFP (Tar-GFP) was expressed in receptor-less cells and observed with total internal reflection fluorescence microscopy (TIRFM). Many fluorescent spots were moving throughout lateral membrane while immotile spots were also observed. Trajectories of moving spots in single cells suggest that the spots move through helical paths. This pattern was lost by the addition of A22 which depolymerizes the filament of the actin-like protein MreB, suggesting that the movement of chemoreceptor clusters are restricted by the actin-like cytoskeleton. Detailed analyses of the effect of A22 on the movement of Tar-GFP are in progress. We are also examining whether the moving receptors are associated with other chemotaxis signaling proteins such as $\mathrm{CheA}$ and CheW.

\section{P-236ネオニコチノイドーアセチルコリン結合タンパク質複合体の結晶 構造解析}

Crystal structures of an acetylcholine binding protein complexed with neonicotinoids

Makoto Thara(1), Toshihide Okajima(2), Atsuko Yamashita(1), Takuma Oda(3), Yuji Ashikawa(1), David B. Sattelle(4) and Kazuhiko Matsuda(3). (1:RIKEN SPring-8 Center; 2:ISIR, Osaka University; 3: Department of Applied Biological Chemistry, Graduate School of Agriculture, Kinki University; 4: MRC Functional Genetics Unit, Deptartment of Physiology Anatomy and Genetics, University of Oxford)

Nicotinic acetylcholine receptors (nAChRs) mediate fast cholinergic neurotransmission and are targeted by several classes of drugs for human and veterinary use and crop protection chemicals. Neonicotinoid insecticides show selective toxicity for insects, and can act as $\mathrm{nAChR}$ agonists, antagonists or potentiators. To elucidate the molecular basis for nAChR-neonicotinoid interactions, X-ray crystallographic analysis of acetylcholine binding protein (AChBP), a surrogate protein for nAChRs, in complex with neonicotinoids, was carried out. The crystal structures of AChBP with imidacloprid (IMI) and clothianidin (CTD) have been solved by molecular replacement and refined to 2.56 and $2.70 \AA$ resolution, respectively. Neonicotinoids bind at the subunit interface where nicotine and other agonists also bind. The aromatic rings of neonicotinoids are anchored by hydrogen bonds (HBs) to the backbone carbonyl and amide via a water molecule, as is the case for nicotine binding to $\mathrm{AChBP}$. Guanidine moieties of IMI and CTD stack with the side chain of W185, while the nitro group of IMI but not that of CTD forms HB with the side chain of Q55. Furthermore, CH-\&pi contacts between the methylene bridge of IMI and the side chain of W143 have been observed, however CTD lacking corresponding methylene, forms a HB with the backbone carbonyl of W143 and NH at position 1 Thus, the guanidine and nitro moieties of neonicotinoids can play significant role in the selective and diverse nicotinic actions.

\section{P-237 マウスにおけるうま味の受容・伝達メカニズムの解析}

\section{Reception and transduction systems for umami taste in mice}

Ryusuke Yoshida (1), Keiko Yasumatsu (1), Shinya Shirosaki (1), Yuriko Kawato (1), Yoshihiro Murata (1), Noriatsu Shigemura (1), Kiyohito Nakashima (2), Robert F. Margolskee (3), Yuzo Ninomiya(1). (1: Sect. of Oral Neurosci., Grad Sch of Dental Sci, Kyushu Univ; 2: Dept of Chem, Asahi Univ Sch Dent; 3: Dept of Physiol \& Biophys, Mount Sinai Sch Med, USA)

Umami taste responses are initiated by G-protein coupled receptors and transduced via G-protein signaling cascade, which ultimately activates the taste-transduction channel (TRPM5). Mice lacking one of these component, such as T1R3 (umami taste receptor component) or TRPM5, still showed umami taste responses, suggesting existence of multiple receptor and transduction systems for umami taste. In this study, we analyzed response properties of individua glutamate sensitive fungiform taste cells and chorda tympani fibers in mice, then, investigated reception and transduction mechanisms for these responses Recordings from mouse single fibers and taste cells revealed that both glutamate sensitive fibers and taste cells were classified into sweet-best (S-type) and mono sodium glutamate (MSG) -best (M-type). Each type was further classified into 2 subgroups: one type showing synergistic effect between MSG and IMP (S1, M1) and the other type showing no synergism (S2, M2). In T1R3- or TRPM5-KO mice S1-type was absent, but S2, M1 and M2 types still remained, supporting the existence of multiple receptors, transduction pathways for umami taste. Glutamate responses of $\mathrm{M}$-type taste cells and fibers were reduced by addition of metabotripic glutamate receptor antagonists, AIDA and $\mathrm{CPPG}$, suggesting that mGluR1 and mGluR4 may function as umami taste receptors in M-type cells. These results suggest that umami taste is mediated by multiple receptor and transduction systems in the taste bud of mice.

\section{P-238 大腸菌アスパラギン酸受容体Tar HAMPドメインのシグナル伝達お よび細胞内局在における役割}

Role of the HAMP domain of the bacterial aspartate chemoreceptor Tar in signaling and subcellular localization

Noriko Ohta(1,2,3), Hiroki Irieda(1,2,3), Michio Homma(1), Ikuro Kawagish (2,3).(1:Division of Biological Science, Graduate School of Science, Nagoya University; 2: Research Cente for Micro-Nano Technology, Hosei University; 3: Department of Frontier Bioscience, Faculty of Engineering, Hosei University)

Four chemoreceptors (MCPs) and an MCP-like protein (the redox sensor Aer) of Escherichia coli form a huge cluster at a cell pole with a "trimer of dimmers" as a building unit. Receptor clustering has been implicated in signal amplification and gain control, but the molecular mechanisms of clustering and localization are poorly understood. The HAMP domain which connects the transmembrane helix to the adaptation/signaling domain has been implicated in transmembrane signaling and proton sensing. Our previous study on a series of chimears between an MCP (Tar) and the osmosensor histidine kinase EnvZ suggest that the HAMP domain is also involved in polar localization. We found that Tar mutants that have substitutions for Pro-219 in the HAMP domain are localization-deficient but can localize when expressed with Aer, which cannot localize when expressed alone. In vivo cross-linking assays showed that the most severe mutation drastically reduces the amount of the cross-linked trimer of Tar. Thus, the substitution at the HAMP domain may alter the configuration of the cytoplasmic domain, which impairs the formation and/or structure of the trimer of dimer. We also examined the roles of His-226 and His-256 that are suspected to be involved in signaling and proton sensing. Some mutations at these positions impaired signaling but did not affect localization. We carried out localized random mutagenesis and found several other mutations that affect signaling. We are currently examining localization of these mutant Tar proteins.

\section{P-239 アカハライモリ搝上皮でのGタンパク質の局在}

Localizations of G-proteins in the olfactory epithelium of the newt, Cynopus pyrrhogaster

Masataka Takashima, Ken Sawada and Tatsuo Iwasa. (Division of Science for Composite Functions, Graduate School of Muroran Institute of Technology)

Olfactory sensation in the ciliary membrane of the olfactory neuron begins with a ligand binding to the olfactory receptor (OR). The binding of an odorant molecule to $\mathrm{OR}$ triggers the activation of $\mathrm{G}_{\text {olf }}$ and adenylyl cyclase.

We previously reported the cloning and expression of the newt OR CDNA, $C p$-ORI. In situ hybridization revealed that cells producing Cp-ORI mRNA were scattered throughout the newt olfactory epithelium (OE) and did not form a cluster, and that two kinds of newt lipocalin superfamily genes showed distinct expression patterns in Bowman's glands. Cp-Lip mRNA were distributed in almost all Bowman's glands, whereas $C p$-OSP mRNA were only in Bowman's glands of dorsal and septal region. These findings suggest the possibility of odorant pre-discrimination within the nasal mucosa.

In order to study the other signaling proteins, we obtained eight cDNA clones encoding $\mathrm{G} \alpha_{\mathrm{olf}}, \mathrm{G} \alpha_{\mathrm{i} 1}, \mathrm{G} \alpha_{\mathrm{i} 2}, \mathrm{G} \alpha_{\mathrm{i} 3}, \mathrm{G} \alpha_{0}, \mathrm{G} \alpha_{\mathrm{t}}, \mathrm{G} \alpha_{11}$, and $\mathrm{G} \alpha_{14}$ from the newt nasal organ. Based on western blot analysis, anti-G $\alpha_{q / 11}$ and anti-G $\alpha_{0}$ antibodies reacted with proteins of appropriate size, corresponding to $\mathrm{G} \alpha$ proteins. The localizations of G-proteins on the newt nasal organ were investigated by immunohistochemistry. The immunoreactivity of $\mathrm{G \alpha}_{\mathrm{q} / 11}$ was observed intensively in the duct region of the newt $\mathrm{OE}$. The immunoreactivity of $\mathrm{G} \alpha_{\mathrm{s} / \mathrm{ol}}$ was found in the apical surface of the $\mathrm{OE}$, but not in that of vomeronasal organ. Based on these results, we will discuss on the distributions of several G-proteins and the other signaling proteins.

\section{P-240 活動電位を発生する味細胞からの ATP 放出におけるへミチャネル の関与}

Hemichannels involved in ATP release from taste cells with action potentials

Yoshihiro Murata (1), Ryusuke Yoshida (1), Toshiaki Yasuo (1), Yuchio Yanagawa (2), Kunihiko Obata (3), Hiroshi Ueno (4), Robert F. Margolskee (5) and Yuzo Ninomiya (1) (I: Sect Oral Neuroscience, Graduate School of Dental Science, Kyushu Univ; 2: Gumma Univ Graduate School of Medicine; 3: RIKEN; 4: Lab Applied Microbiology and Biochemistry. Nara Women's Univ; 5: Mount Sinai School of Medicine)

Taste information is transmitted from taste cells to gustatory nerve fibers through synapses. However, taste cells with sweet, bitter and/or umami receptors (type II cells) are lacking synapses, and the mechanisms have not been elucidated. Recent reports have highlighted the role of ATP as a key neurotransmitter. The reports with ATP biosensors have shown that type II cells are able to release ATP through hemichannels. In previous work, we presented that type II cells in response to a sweet or bitter compound release ATP in a firing rate-dependent manner. Here we examined the effects of hemichannel blockers on the ATP release. Action potentials were recorded with the electrode basolaterally attached to a single taste cell. The electrode solution was collected and applied for luciferase assay to determine the ATP. To identify type II cells, we used gustducin-GFP transgenic mice. GFP-positive cells increased the firing rate in response to a bitter compound (cyclohexamide) in the presence of a hemichannel blocker, carbenoxolone, in both the electrode and the bath solutions. The amount of ATP in the electrode solution was reduced depending on the concentrations of carbenoxolone. The results suggest that hemichannels are crucial for firing rate-dependent ATP release from taste cells without conventional synapses. Supported by KAKENHI 18077004, 18109013 (YN), 19791367 (RY), and 20791355 (YM).

\section{P-241 可視光による光活性化可能な生体機能分子の開発と応用}

Development And Application Of Biomolecules With Protecting Group Removable By Visible Light Irradiation

Nobuhiro Umeda (1,2), Yasuteru Urano (1,3), Tetsuo Nagano (1,2). (1: Graduate School of Pharmaceutical Sciences., Univ of Tokyo; 2: JST CREST; 3: JST PRESTO)

Spatial and temporal distribution of bio-active molecules is important for various biological events in cell, and cell tissue. Caged compounds are biomolecules whose bio-activity is masked by photo-removable protecting group (PRPG), which can be activated by light irradiation. They are known as one of the most powerful molecular tools to manipulate the spatio-temporal distribution of 
bio-active molecules. However, since so far developed caged compounds require high energetic UV light for their activation, cytotoxicity and poor permeability of the irradiation light restrict the range of their applications. Here, we report a widely known fluorophore BODIPY as a novel PRPG which can be photolyzed with extremely longer wavelength visible light. Through the investigation of photo-chemical properties of BODIPY derivatives, BODIPY derivatives bearing phenol derivatives at 4 position whose fluorescence are quenched due to its intramolecular photo-induced electron transfer released the phenols upon irradiation of visible light. Based on this finding, we developed novel caged glutamic acid which can be activated with far less cytotoxic and more tissue-permeable visible light irradiation. In addition, since the activating efficiency of the caged compounds is comparable to the existing ones, we can use them in much the same way as the widely used caged compounds with less cytotoxicity and more permeability of the irradiation.

\section{P-242 二種の大腸菌走化性受容体による混合クラスター形成と受容体間 相互作用}

Lateral communication between distinct types of bacterial chemoreceptors in a mixed cluster

Hiroki Irieda (1,2), Michio Homma (1) and Ikuro Kawagishi (2,3,4,5). (1: Div. of Biological Science, Grad. Sch. of Science, Nagoya Univ.; 2: Research Center for Micro-Nano Technology, Hosei Univ; 3: Dept. of Frontier Bioscience, Fac. of Bioscience and Applied Chemistry, Hosei Univ:; 4: Dept. of Frontier Bioscience, Fac. of Engineering, Hosei Univ.; 5: Dept. of Materials Chemistry, Grad. Sch. of Engineering, Hosei Univ.)

The chemotaxis of Escherichia coli is one of the most extensively studied sensory systems. Environmental stimuli are sensed by methyl-accepting chemotaxis proteins (MCPs), including Tar for aspartate and Tsr for serine, which regulate the cytoplasmic histidine kinase CheA. MCP homodimers cluster at a cell pole together with CheA and the adaptor protein CheW. This clustering is supposed to contribute signal amplification by facilitating interactions between MCP dimers. It is believed that three MCP dimers interact with each other in the periplasmic and cytoplasmic domains to form a hexagonal array. However, the molecular mechanism underlying such MCP communications is obscure. Using in vivo disulfide crosslinking assays, we examined the dimer-to-dimer interactions between Tar and Tsr. Co-expression of Cys-mutant versions of Tar and Ts resulted in crosslinked Tar-Tsr heterodimer, which is predicted to result from crosslinking between Tar and Tsr homodimers. Moreover, aspartate binding to Tar affected not only Tar-Tar crosslinking but also Tar-Tsr and Tsr-Tsr crosslinking, a result which is consistent with horizontal signal propagation via interaction between MCP dimers. To understand the precise mechanism of signal amplification, more detailed structural information of the cluster is indispensable. We therefore set out to purify and analyze trimers of dimers of MCP that are crosslinked at either periplasmic or cytoplasmic positions.

\section{P-243 コレラ菌・海洋ビブリオ菌のアミノ酸走性に関与する受容体ホモ ログの解析}

Cloning and characterization of chemoreceptor homologs involved in chemotaxis toward amino acids in Vibrio cholerae and related species

So-ichiro Nishiyama (1)(2), Daisuke Suzuki (3), Michio Homma (3) and Ikuro Kawagish (1) (2) (1: Dept of Frontier Bioscience, Faculty of Bioscience and Applied Chemistry, Hose Univ; 2: Research Center for Micro-Nano Technology, Hosei Univ; 3: Division of Biological Science, Graduate School of Science, Nagoya Univ)

Vibrio cholerae, an etiological agent of cholera, shows chemotaxis, which is implicated in pathogenicity as well as survival in various environments. The genome of a classical biotype strain of $V$. cholerae is deduced to encode 45 chemoreceptor homologs, which we name methyl-accepting chemotaxis protein-like proteins (MLPs). Our recent studies revealed that Mlp24 and Mlp37 mediate attractant responses to similar but distinct sets of amino acids. Sequence analyses suggest that these MLPs constitute a subfamily with Mlp8 that has been implicated in colonization of $V$. cholerae in host intestine and MLPs of Pseudomonas aerginosa that are involved in amino acid taxis. The amino acid sequences and the deduced secondary structures suggest that their periplasmic domains are structurally different from the amino acid chemoreceptors of enteric bacteria such as Tsr and Tar. Among the subfamily members, Mlp37 is unique in that it mediates responses to taurine (2-aminoethane sulfonate). We found that marine Vibrio species ( $V$. alginolyticus and $V$. parahaemolyticus) do not respond to taurine. Their genomes are deduced to encode 30 MLPs, but only one of them (tentatively named MlpA) belongs to the subfamily. Interestingly, expression of $V$. alginolyticus $m l p A$ restored taurine taxis of the mlp37 deletion mutant of $V$. cholerae. This result implies involvement of component(s) in $V$ cholerae other than Mlp37. Analyses are in progress to elucidate mechanisms underlying sensing amino acids and other compounds by the members of this subfamily.

1P-244 コレラ菌走化性関連シグナリングシステム III タンパク質の局在 制御

Localization control of components of the chemotaxis-related signaling system III in Vibrio cholerae

Geetha Hiremath (1)(2), Tatsuaki Ebisawa (1)(2), Akhiro Hyakutake(3), Daisuke Suzuki(4), So-ichiro Nishiyama(2)(5), Michio Homma(4), Ikuro Kawagishi(1)(2)(5)(6)(1: Department of Materials Chemistry, Graduate School of Engineering, Hosei University; 2: Research Center for Micro-Nano Technology Hosei University. 3. Research Institute for Microbial Diseases, Osaka University; 4: Division of Biological Science, Graduate School of Science, Nagoya University; 5: Department of Frontier Bioscience, Faculty of Bioscience and Applied Nagoya University; 5: Department of Frontier Bioscience, Faculty of Bioscience and Applied
Hosei University)

Vibrio cholerae, the causative agent of cholera, with a single polar flagellum regulates its movement and chemotaxis. The genome sequence of El Tor and classical strains predicts that the bacterium has three sets of chemotaxis-related signaling proteins or Che proteins (each consisting of a distinct system). Our laboratory previously showed that components of system II (CheA2 and CheY3) directly involved in chemotaxis localize to the flagellated pole constitutively, whereas components of system I (CheA1 and CheY2) localize to a pole under anaerobic (or microaerobic) conditions. However, localization of system III components have not been explored. To get an insight into the functions of system III, we examined their subcellular localization by using GFP fusions. GFP-CheA3 and GFP-CheW2 of system III localized to a pole when incubated without shaking, but their polar localization was lost after vigorous shaking, suggesting that polar localization of the components is controlled in response to changes in energy metabolism, a phenomenon similar to system I. Further analyses of GFP-CheA3 deletion mutants revealed that the carboxy terminal region is responsible for the anaerobic localization of CheA3. CheY4-GFP and GFP-CheY4, however, did not localize even with standing culture. This might result from steric hindrence of GFP or low affinity of CheY4 to CheA3. The polar localization of systems I and III also propose that their components assemble to function in anaerobic environments, such as host intestine.

\section{P-245 細菌化学感覚受容体のフェノール応答に関与する領域の同定}

Identification of the regions involved in phenol-sensing by the bacterial chemoreceptors

Ken Takeuchi, Tomohiro Tokunaga, Tomonori Iwama and Keiichi Kawai. (Faculty of Applied Biological Sciences, Gifu University\}

Bacteria such as Escherichia coli and Salmonella typhimurium show chemotaxis by modulating their swimming pattern. The chemotactic stimuli are sensed by methyl-accepting chemoreceptors embedded in the cytoplasmic membrane. Phenol is more complicated chemotactic stimulus than the others. Many of chemoreceptors recognize this compound as a repellent, but some chemoreceptors recognize as an attractant. Citrate receptor Tcp mediates a repellent response to phenol and serine receptor Tsr mediates a weaker repellent response. But aspartate receptor Tar mediates an attractant response to phenol. Thus, the same chemica stimulus induces opposite responses. However, the molecular mechanism underlying the sensing of phenol is unknown. In this study, we constructed various kinds of chimeras and investigated their phenol-sensing properties by the capillary assay. At first, we examined the phenol-sensing abilities of the chimeras between Tcp and Tar to identify the region determining the polarity of receptor signaling in response to phenol. These experiments showed that a short sequence within the cytoplasmic region of the receptor (Gly245-Glu308 of Tar and Gly244-Glu308 of Tcp) is important for the decision of signaling polarity. Currently, we are analyzing the chimeras between Tcp and Tsr to identify the region responsible for the phenol recognition.

\section{$1 \mathrm{P}-246$ 細菌走化性受容体のセリン認識メカニズムの解析}

Serine recognition mechanism of bacterial chemotactic receptors

Hirotaka Tajima(1,4), Katsumi Imada(2), Mayuko Sakuma(1), Michio Homma(1), Ikuro Kawagishi(3,4,5,6). (1: Dept Biological Science, Graduate School of Science, Nagoya Univ, 2: Graduate School of Frontier BIosciences, Osaka Univ; 3: Dept Materials Chemistr Gradudate School of Engineering, Hosei Univ; 4: Research Center for Micro-Nano Technology Hosei Univ: 5:Dept Frontier Bioscience, Faculty of Bioscience and Applied Chemistry, Hosei Univ; 6: Dept Frontier Bioscience, Faculty of Engineering, Hosei Univ)

Escherichia coli has closely related amino acid chemoreceptors with strict ligand specificity: Tar for aspartate and Tsr for serine. We have determined the apo and serine-bound structures of the periplasmic domain of Tsr. The structures revealed that some of the ligand-binding residues of Tsr are arranged differently from the conserved ligand-binding residues of Tar. Furthermore, many negatively charged residues were arranged around the ligand-binding pocket of Tsr, although positively charged residues were arranged around that of Tar. It is concluded that these alterations of arrangements of residues may be necessary for the ligand specificities of Tsr and Tar. To further understand the ligand recognition mechanism, we prepared and characterized periplasmic fragments of mutant Tsr and Tar as well as those of Tsr-Tar chimeras. Serine binding is supposed to cause a subtle structural change in the Tsr periplasmic domain, which would eventually cause structural change(s) in the cytoplasmic signaling domain to regulate the CheA kinase activity. The three-dimensional structures of the periplasmic domain of Tar and the cytoplasmic domain of Tsr and the HAMP domain of a sensor of unknown function from an extremely thermophilic bacterium have already been determined. However, the full-length structure is prerequisite for our understanding of the most basic question, i.e. how the protein transmits signals across the membrane. We therefore set out to purify and crystallize full-length Tar and Tsr

\section{P-247 コレラ菌走化性関連システム1シグナル伝達複合体の嫌気条件に おける構築}

Assembly of the components of a chemotaxis-related signaling system of Vibrio cholerae under anaerobic conditions

Tatsuaki Ebisawa (1,2), Akihiro Hyakutake (3), Daisuke Suzuki (4), So-ichiro Nishiyama (2,5), Michio Honma (4) and Ikuro Kawagishi $(1,2,5,6)$

The chemotaxis of Vibrio cholerae has been implicated in pathogenicity and survival in various environments. The $V$. cholerae genome has three gene clusters 